\title{
Education and training of quantum electronics specialists in Krasnoyarsk State University
}

Alexander Provorov, A. Sizykh

Alexander Sergeevich Provorov, A. G. Sizykh, "Education and training of quantum electronics specialists in Krasnoyarsk State University," Proc. SPIE 1603, Education in Optics, (1 March 1992); doi: 10.1117/12.57901

SPIE. Event: Education in Optics, 1991, Leningrad, Russian Federation 


\section{Education and training of quantum electronics specialists \\ in Krasnoyarsk State University \\ Provorov A.S., Sizykh A.G. \\ Krasnoyarsk State University}

The quantum electronics, as a comparatively new branch of physics is developing quickly and at the same time the teaching of this specialization in the universities should be improving.

In Krasnoyarsk State University the specialization "Quantum electronics" was introduced in 1988. As the basis for the curriculum of this specialization there were taken the following items:

1. The purposeful training of specialists for research institutions, Academy of sciences, branch institutes, factory laboratories.

2. The combination of theoretical and applied subjects.

3. The delivering of lectures on theory and seminars, based on the modern achievements of the quantum electronics.

4. The development of the business and creative initiative by means of introducing of the optional subjects, of the rating system of knowledge evaluation.

5. The working out and delivering of special subjects according to the order of specialists sponsors.

The curriculum of specialization is carried out during the five terms (terms 5-9) (table 1). The succession of delivering of specialized subjects is organized in accordance with level of students knowledge in theoretical physics with the gradual complication of subjects content. At the third year they study such subjects as "Coherent Optics and Holography" and the "Integral Optics and the system of Information Transfer" as well, which are based on the electromagnetic theory of light. At the fourth year (in accordance with progress in delivering of quantum mechanics, electrodynamics and statistical physics) they study. "The physics of gas discharge", "The laser physics" and "Spectroscopy", including atomic and molecular spectroscopy of linear and unlinear phenomena.

One of the main subjects "The laser physics" is devoted to the detailed consideration of the physical processes in optic quantum generators of various types. The physics of the gas discharge gives the fundamentals for studying the laser with gas discharge pumping but has the same time the significance of its own. 
In the eighth term, they teach subject "The laser ohotophysics of atomic-molecular media" in which the unified view-points of consideration of the large group of the elementary photophysic processes is represented, which are taking place in laser media with the interaction of laser radiation with substance. At the same term they study the course "Laser equipment and usage". They consider the usage of lasers in various spheres of science, technology. The logic supplement of this course is delivered in the ninth term course "The physical bases of the laser technologies". The characteristic feature of these two subjects is its practical orientation in combination with strict physical line of reasoning.

In the eighth term they begin to teach two subjects up to the ninth term. These are "Computers in the physical experiment" and "Optic waves in condensed media". The aim of the first subject consists in deep mastering by the students of the methods of computer usage for the control of the optical-spectral experiment and its results processing. The second subject represents detailed and profound study of laser optics and spectroscopy of solids and liquids. The both of above-mentioned subjects are delivered by the scientists from academic institutes in order to more profoundy train specialists for work in the field of scientific research.

If specialized course "Computers in the physical experiment" it wholly devoted to the experiment automatation the special subject "The numeric modelling of gas lasers (9-th term) shows the ways of the machine modelling of the radiation generation in gas lasers including powerful $\mathrm{CO}_{2}$ - lasers and on practical examples shows the students how to make calculations with the help of computers.

The specialized course "Quantum theory of light" concludes the training of the laser physicists, giving the students the nation about the quantum and statistical description of the light.

The theoretical education of the future specialists in the quantum theory is supplemented by a great deal of practical work in research laboratories in the fields of timely scientific directions under the supervision of the skilled specialists of research institutes.

It should be noted, that initial knowledge in quantum physics the students acquire in the framework of the part of the General Physics with the same name which is in full scope delivered by the instructors of the specialising chair of quantum electronics. The methodical basis of the teaching of the "Quantum physics" consists in the "rating system" according to which the students have the right to put themselves the final marks for this subject. The main forms of the educational work are practical laboratory works, the solving of the problems, the profound study of the selected part of the course, the presentation of essay, the independent elaboration and carrying out of the original experiment on the basis of laboratory work and solving of tasks of higher complexity. All the kinds of studying work[I] 
are evaluated by the certain amount of points: laboratory works 1,6 ; seminars - 1,5; obligatory educational tasks - 0,6; the report on the essay - 0,2; oral examination - 0,3; the original experiment 0,5 ; the problems of higher complexity - 0,4. The sum of points in all kinds of control works, including examination ( 1,5 points) gives the final estimation of the knowledge. The system proves efficient, because it gives the possibility to involve students in carrying out the interesting work demanding creativity.

The necessary thing for the successful implementation of the special education is the availability of textbooks, study aids and instructions for practical and laboratory works. The speciality "Quantum electronics is in general well provided with literature, taking into account the world bank of the special literature. But it is very important to have study aids which could be used as concise "guides" in the course and make it possible to supplement more extensive textbooks with current information.

The members of the faculty have written and published several study aids. One of them helps the students to study special course "Laser equipment and usage" [3] and the other - the special course "The spectroscopy" [2].

We assume, that the student carrying out the educational task should have at his disposal more extensive information in the subject studied, then it is necessary for the solving of some particular case of the more generally put task. Such an approach grants to the student the right of choice of variety of tasks and the ways of its solving. We stick to this principle in teaching the parts of general physics and special courses. The usage of this principle in laboratory work makes it possible for the student to acquire skills of independent orientation in the field of modern experiment in laser physics and spectroscopy. As an example of such approach one can give the methodical instructions for laboratory work in quantum physics "The Oscilating-rotational structure of electron spectra of CN-Radical" [4] compiled and published by our chair. Among the tasks of this work there the pattern calculation of the spectrum of CN-Radical with computer aid, the experimental estimation of oscilating and rotational constants, the interaction analysis of the spectroscopic phenomena observed during the electronic excitation of binary molecule.

In conclusion we express gratitude to the organizing committee of the educational conference "Education in optics" for the possibility of exchange of useful methodical and scientific information in the world community of scholars and teachers working in the sphere of education in Optics. 
The Krasnoyarsk State University

THE CURRICULUM

OF THE SPECIALIZATION "QUANTUM ELECTRONICS"

\begin{tabular}{|c|c|c|c|c|c|c|}
\hline NN & The subjects & Term & $\begin{array}{l}\text { The total } \\
\text { amount of } \\
\text { acad. huors }\end{array}$ & Lectures & Seminar & $\begin{array}{l}\text { Laboratory } \\
\text { works }\end{array}$ \\
\hline 1. & $\begin{array}{l}\text { The coherent optics } \\
\text { and holography }\end{array}$ & 5 & 54 & 36 & 18 & - \\
\hline 2. & $\begin{array}{l}\text { The integral optics } \\
\text { and systems of infor- } \\
\text { mation transfer }\end{array}$ & -6 & 51 & 34 & 17 & - \\
\hline 3. & $\begin{array}{l}\text { The physics of gas } \\
\text { discharge }\end{array}$ & 7 & 36 & 36 & - & - \\
\hline 4 . & The laser physics & 7 & 72 & 36 & 18 & 18 \\
\hline 5. & Spectroscopy & 7 & 36 & 36 & - & - \\
\hline 6. & Spectroscopy & 8 & 34 & 34 & - & - \\
\hline 7. & $\begin{array}{l}\text { The laser equipment } \\
\text { and application }\end{array}$ & 8 & 51 & 34 & 17 & - \\
\hline 8. & $\begin{array}{l}\text { The optical waves } \\
\text { in condensed media }\end{array}$ & 8 & 51 & 51 & - & - \\
\hline 9. & $\begin{array}{l}\text { Computers in the phy } \\
\text { sical experiment }\end{array}$ & & 34 & 17 & - & 17 \\
\hline 10. & $\begin{array}{l}\text { The laser photophy- } \\
\text { sics of atomic-mo- } \\
\text { lecular media }\end{array}$ & 8 & 34 & 34 & - & - \\
\hline 11. & $\begin{array}{l}\text { The optical waves in } \\
\text { the condensed media }\end{array}$ & n 9 & 45 & 30 & 15 & - \\
\hline 12. & $\begin{array}{l}\text { Computer in the phy- } \\
\text { sical experiments }\end{array}$ & -9 & 30 & 15 & - & 15 \\
\hline 13. & $\begin{array}{l}\text { The numeric model- } \\
\text { ling of gas lasers }\end{array}$ & 9 & 30 & & 30 & - \\
\hline 14 . & $\begin{array}{l}\text { The physical bases } \\
\text { of laser technolo- } \\
\text { gies }\end{array}$ & 9 & 30 & 30 & - & - \\
\hline 15 . & $\begin{array}{l}\text { The quantum theory } \\
\text { of light }\end{array}$ & 9 & 30 & 30 & - & - \\
\hline
\end{tabular}




\section{BIBLIOGRAPHY}

1. A.S.Provorov and A.V.Sorokin, Activation of Educational Work in Teaching of the Parts of General Physics. Theses of the Reports at the Conference-Seminar "Problems of Physics Education in the Institutes". Novosibirsk, p. 48-49, 1991.

2. A.G.Sizykh, "Rotational and Oscillating Spectroscopy of Polyatomic Molecules". Lecture Text of Special Course. Krasnoyarsk, 1988.

3. A.S.Provorov and A.G.Sizykh and A.V.Sorokin, Lasers Application in Science, Equipment and Technology. Study Aid. Krasnoyarsk, 1988 .

4. A.G.Sizykh and A.V.Sorokin, "Oscillating-Rotational Structure of Electronic Spectra of the Cyanogen Radical". Methodological Instructions for Laborotory Work in Quantum Physics. Krasnoyarsk, 1990. 